\title{
Resectable Head and Neck Squamous Cell Carcinoma
}

National Cancer Institute

\section{Source}

National Cancer Institute. Resectable Head and Neck Squamous Cell Carcinoma. NCI

Thesaurus. Code C132012.

Squamous cell carcinoma of the head and neck which is amendable to surgical removal. 